\title{
MISKONSEPSI SISWA SEKOLAH DASAR PADA PEMBELAJARAN BILANGAN DESIMAL
}

\author{
Rahmah Johar \\ Fitriadi \\ Mahdalena \\ Rusniati \\ Prodi Magister Pendidikan Matematika Program Pascasarjana Universitas Syiah Kuala. \\ Jl. Tgk. Chik Pante Kulu No. 5 Unsyiah Darussalam Banda Aceh. \\ Email: fitriadi.mahmud@yahoo.com
}

\begin{abstract}
The aim of this study is to describe students' minsconception at decimal numbers learning. The research subjects are IV grade students SDN 67 and MIN Tungkob Aceh Besar. Qualitative research method using observation instrument and learning test on decimal numbers material were applied in this tudy. The results of this study is in the form students' mistakes deccription in understanding the concept of deciding decimal numbers between two integers and change fractions into decimal numbers, and students' mistakes in solving the addition operation of decimal numbers. It is indicated that the causes of the misconception are sample questions are less varied so that generalizations become wrong and the limited time in using props so students tend to use stackable summation like the summation of integers.
\end{abstract}

Keyword: misconception, elementary school students, decimal numbers

\begin{abstract}
Abstrak: Penelitian ini bertujuan mendeskripsikan bentuk miskonsepsi siswa pada pembelajaran bilangan desimal. Subjek penelitian adalah siswa kelas IV SDN 67, dan MIN Tungkob Aceh Besar. Data penelitian melalui observasi dan tes pembelajaran materi bilangan desimal. Analisis secara kualitatif. Hasil penelitian berupa siswa salah memahami konsep menentukan bilangan desimal diantara dua bilangan bulat, dan mengubah pecahan menjadi bilangan desimal, dan siswa salah melakukan operasi penjumlahan bilangan desimal. Penyebab miskonsepsi yaitu contoh soal kurang bervariasi sehingga generalisasi yang dilakukan menjadi keliru dan waktu yang diberikan menggunakan alat peraga terlalu singkat sehingga siswa cenderung menggunakan cara penjumlahan bersusun seperti menjumlahkan bilangan bulat.
\end{abstract}

Kata kunci: miskonsepsi, siswa sekolah dasar, bilangan desimal.

Matematika merupakan salah satu cabang ilmu yang perlu diperhatikan dalam pembelajaran. Karena matematika merupakan dasar dari ilmu pengetahuan dan teknologi, sehingga matematika perlu dipelajari, dipahami, dan dikuasai, karena pada kenyataannya matematika juga merupakan salah satu pengetahuan yang mempunyai peranan penting dalam berpikir yaitu sebagai alat untuk memecahkan masalah dalam kehidupan sehari-hari.
Proses pembelajaran merupakan salah satu aktivitas yang mengarahkan siswa untuk memahami konsep pembelajaran dengan sebaik-baiknya. Pemahaman tentang konsep merupakan kompetensi penting dalam belajar matematika. Penguasaan terhadap banyak konsep di dalam matematika memungkinkan siswa mampu menyelesaian masalah dengan lebih baik. Keadaan tersebut terjadi karena para siswa sering berhadapan dengan aturan-aturan berupa 
aksioma, definisi, teorema, rumus atau algoritmaalgoritma. Semua aturan tersebut didasarkan pada konsep-konsep yang saling berkaitan. Siswa yang mempelajari matematika dapat menguasai konsepkonsep selanjutnya di dalam matematika, apabila konsep-konsep yang mendasarinya sudah dikuasai.

Adapun beberapa hasil penelitian yang mengatakan bahwa, pembelajaran konsep kesamaan dan ketaksamaan bilangan desimal dengan menggunakan kalkulator dapat membantu meyakinkan siswa tentang konsep kesamaan dan ketaksamaan bilangan desimal (Winarni, 2012; Wirda, dkk, 2015). Selain itu, pada pembelajaran operasi penjumlahan bilangan desimal, konsep nilai tempat berperan sebagai pengetahuan dasar, melalui serangkaian aktivitas (LT) yang telah dirancang guna membantu siswa dalam pembelajaran operasi penjumlahan bilangan desimal dan juga memberikan motivasi kepada siswa selama proses pembelajaran (Afriansyah \& Putri, 2013; Ristanti, 2016).

Pemahaman konsep sangat penting dalam proses belajar mengajar atau proses pembelajaran matematika, karena matematika mempunyai sifat yang saling berkaitan satu sama lain. Sebagai contoh ketika mempelajari materi bilangan desimal terkait dengan konsep bilangan pecahan, bilangan bulat dan garis bilangan. Fakta yang terjadi selama proses pembelajaran siswa tidak selalu menyerap informasi sepenuhnya, terlebih lagi pada materi bilangan desimal yang memuat banyak konsep. Ketidaksesuaian pemahaman konsep tersebut seringkali disebut sebagai miskonsepsi. Novak dan Gowin (dalam Gül \& Mustafa, 2008) menyatakan bahwa miskonsepsi merupakan suatu interpretasi konsep-konsep dalam suatu pernyataan yang tidak dapat diterima. Selanjutnya Roselizawati, et al, (2014) menyebutkan bahwa matematika merupakan pembelajaran yang bersifat akumulatif, artinya selalu terkait dengan pengetahuan sebelumnya. Oleh karena itu, jika siswa tidak mampu mengasimilasi dan mengakomodasi keterkaitan pengetahuan, maka akan terjadi kesalahan dalam memahami konsep.

Miskonsepsi pada matematika akan berpengaruh pada hasil belajar, karena konsep pada matematika saling berkaitan satu dengan lainnya. Suparno (2013) menyebutkan berbagai miskonsepsi yang terjadi pada siswa akan mengakibatkan terjadinya kesalahan-kesalahan siswa dalam menyelesaikan soal sehingga berpengaruh terhadap hasil belajar. Oleh sebab itu, miskonsepsi yang terjadi tidak boleh bertahan lama pada diri siswa. Namun demikian, bagi guru mengubah miskonsepsi yang sudah melekat pada siswa bukan pekerjaan yang mudah, apalagi mikonsepsi tersebut dapat membantu memecahkan persoalan tertentu.

Persoalan miskonsepsi pada bilangan desimal yang dialami oleh siswa pada bilangan desimal terjadi secara beragam. Pramudiani (2011) menyebutkan ketika siswa diminta untuk membandingkan bilangan antara 12,17 dengan 12,4, maka siswa memilih bilangan 12,17 lebih besar dari 12,4. Para siswa menganggap bahwa 17 lebih besar dari 4 . Hasil penelitian lain tentang miskonsepsi siswa pada bilangan desimal disebutkan oleh Ubuz dan Yayan (2010) bahwa kekeliruan yang paling umum dalam persoalan penjumlahan bilangan desimal adalah ketika menambahkan angka terakhir di belakang koma, misalnya menambahkan 0,1 ke 4,256 dan 6,98 , kemudian siswa memberikan jawaban yang keliru 4,257 dan 6,99 daripada jawaban 4,356 dan 6,98 .

Sehubungan dengan uraian di atas, maka dilakukan penelitian tentang miskonsepsi siswa pada pembelajaran bilangan desimal di SDN 67 dan MIN Tungkob Aceh Besar. Tujuannya adalah untuk mengetahui bentuk miskonsepsi yang dialami oleh siswa dalam pembelajaran bilangan desimal dan saran untuk mengatasinya.

\section{METODE}

Jenis penelitian ini adalah penelitian kualitatif untuk mendeskripsikan bentuk miskonsepsi siswa padapembelajaranbilangandesimaldanmemberikan saran yang sesuai dalam mengatasi miskonsepsi siswa pada materi bilangan desimal. Subjek penelitian ini dipilih berdasarkan pengamatan yang dilakukan selama proses pembelajaran bilangan desimal di SD Negeri 67 Banda Aceh dan MIN Tungkob Aceh Besar. Berdasarkan pengamatan tersebut terdapat beberapa siswa yang mengalami masalah, namun tulisan ini hanya membahas tiga siswa yang mewakili siswa dengan miskonsepsi yang unik.

Data penelitian dikumpulkan melalui tes dan observasi. Tes berupa kuis diberikan pada setiap akhir pertemuan. Observasi yang dilakukan bertujuan untuk mengetahui penyebab terjadinya miskonsepsi pada siswa ditinjau dari proses pembelajaran yang dilakukan guru. Data observasi dida- 
patkan dengan menggunakan catatan lapangan sesuai kejadian yang terjadi. Selain menggunakan catatan lapangan, untuk mendapatkan data yang kredibel peneliti merekam semua kegiatan pembelajaran menggunakan kamera dan mengambil foto. Penelitian ini menggunakan triangulasi teknik yaitu melakukan pengecekan data yang diperoleh melalui observasi pada pembelajaran bilangan desimal dan memberikan tes serta pengambilan dokumentasi berupa hasil jawaban siswa.

\section{HASIL}

\section{Bentuk Miskonsepsi Siswa A}

Berdasarkan hasil kerja Siswa A, ditemukan miskonsepsi mengenai bilangan desimal yang terletak diantara dua buah bilangan bulat. Adapun bentuk miskonsepsi siswa A adalah sebagai berikut.

\section{Tuliskan bilangan pada titik-titik berikut.}

a.

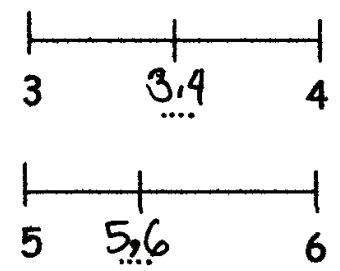

Gambar. 1. Bentuk Miskonsepsi Siswa A

Gambar 1 menunjukkan pemahaman siswa A tentang bilangan desimal yang terletak antara 3 dan 4. Hasil tes yang dikerjakan oleh siswa A menunjukan pemahaman konsep yang keliru dalam menentukan bilangan desimal yang terletak diantara dua bilangan bulat. Meskipun tanda garis yang ditentukan letaknya tepat di tengah-tengah antara bilangan 3 dan 4 tetapi siswa A menuliskan 3,4 sebagai bilangan yang terletak diantara 3 dan 4 . Selanjutnya pada soal kedua siswa A menuliskan bilangan desimal yang terletak antara 5 dan 6 adalah 5,6. Berdasarkan hasil observasi, keadaan ini dipengaruhi oleh contoh soal yang diberikan oleh guru ketika proses pembelajaran bilangan desimal. Pada proses pembelajaran guru memberikan contoh soal berupa bilangan desimal yang terletak tepat di tengah antara 4 dan 5 adalah 4,5. Keadaan tersebut membuat siswa A salah memahami konsep, karena berpikir bahwa ketika diberikan contoh soal tentang bilangan yang terletak di tengah antara 4 dan 5 adalah
4,5. Sehingga siswa A menganggap 4,5 diperoleh dari penggabungan antara 4 dan 5. Akibatnya ketika guru memberikan soal tentang bilangan desimal yang terletak di tengah antara 3 dan 4 . Maka siswa A memahaminya adalah penggabungan 3 dan 4, sehingga jawabannya adalah 3,4. Begitu juga dengan soal bilangan desimal diantara 5 dan 6, walaupun tanda garis yang ditentukan belum sampai di tengah-tengah antara 5 dan 6 siswa A juga berpikir bahwa nilainya adalah penggabungan angka 5 dan 6 sehingga jawabannya adalah 5,6.

\section{Miskonsepsi yang Terjadi pada Siswa B}

Berdasarkan hasil kerja siswa B, ditemukan miskonsepsi mengenai mengubah pecahan menjadi bilangan desimal. Adapun bentuk miskonsepsi siswa $B$ adalah sebagai berikut.

\section{Tuliskan bilangan desimal untuk pecahan berikut}
a. $\frac{3}{10}=3,10$
b. $\frac{7}{10}=7.10$

Gambar 2. Bentuk Miskonsepsi Siswa B

Berdasarkan Gambar 2 dapat dijelaskan mengenai miskonsepsi siswa $\mathrm{B}$ dalam mengubah pecahan menjadi bilangan desimal. Siswa B menuliskan bahwa nilai pecahan $\frac{3}{10}$ diubah ke bilangan desimal menjadi 3,10. Siswa B beranggapan bahwa angka yang terdapat pada pecahan yaitu 3 dan 10 diubah ke bilangan desimal cukup dengan menggabungkan kedua angka tersebut kemudian dibuat tanda koma sehingga menjadi 3,10. Begitu juga dengan soal lain, siswa B mengubah pecahan $\frac{7}{10}$ menjadi bilangan desimal dengan bentuk 7,10 . Siswa B juga memahami bahwa mengubah pecahan tersebut dapat dilakukan dengan menggabungkan antara pembilang dan penyebut kemudian memberikan tanda koma. Berdasarkan hasil observasi kesalahan ini terjadi akibat waktu menjelaskan materi tersebut oleh guru yang sangat singkat.

\section{Miskonsepsi yang Terjadi pada Siswa C}

Berdasarkan jawaban siswa $\mathrm{C}$ pada lembaran tes, ditemukan miskonsepsi mengenai operasi 
penjumlahan bilangan desimal. Adapun bentuk miskonsepsi Siswa $\mathrm{C}$ adalah sebagai berikut.

2. Tentukan hasil dari penjumlahan dan pengurangan berikut

$$
\begin{aligned}
& \text { a. } 0,3+0,5=.0,8 \\
& 12,37 \\
& \text { b. } 12,37+1,4=12,51 \rightarrow \frac{1,4}{12,51}+
\end{aligned}
$$

Gambar 3. Bentuk Miskonsepsi Siswa C

Gambar di atas menunjukan bentuk miskonsepsi siswa dalam memahami aturan operasi penjumlahan bilangan desimal. Siswa $\mathrm{C}$ memandang bilangan desimal sebagai bilangan bulat sehingga mengakibatkan kesalahpahaman ketika melakukan operasi penjumlahan. Pada gambar 3 jelas terlihat siswa $\mathrm{C}$ mengabaikan koma yang ada pada kedua bilangan tersebut, akibatnya operasi bilangan desimal dilakukan seperti operasi bilangan bulat. Seharusnya jawaban yang tepat untuk penjumlahan $12,37+1,4$ adalah 13,77 bukan 12,51. Berdasarkan hasil observasi kesalahan konsep ini terjadi karena siswa C ketika melakukan operasi penjumlahan bilangan pecahan langsung menggunakan cara penjumlahan bersusun seperti operasi bilangan bulat.

\section{PEMBAHASAN}

Menurut Lochead \& Mestre (dalam Allen, 2007) salah satu teknik menghilangkan miskonsepsi dengan cara menyelidiki dan menemukan alasan yang konseptual. Langkah pertama yang dapat dilakukan adalah dengan memberikan pemahaman yang bertahap dari tiap konsep. Kegiatan tersebut dapat diawali dengan sesuatu yang kongkrit, ikonik dan simbolik sesuai tahap berpikir siswa. Berdasarkan tiga hal tersebut guru dapat menghadapkan siswa dengan menyajikan contoh yang berlawanan dengan miskonsepsinya. Dengan adanya pemberian contoh yang berlawanan tersebut, maka akan muncul penemuan sendiri yang bersifat lebih kuat. Miskonsepsi itu akan tergantikan ketika terjadi perubahan konsepsi siswa. Berbagai metode, model, strategi atau pendekatan dapat dikembangkan oleh guru sesuai dengan kondisi kelas.

Untuk membantu siswa yang mengalami miskonsepsi pada masalah seperti yang dialami siswa A, guru dapat menggunakan media yang berbentuk permukaan timbangan dengan skala 0 sampai 4 seperti pada Gambar 4. Media model permukaan timbangan tersebut bertujuan untuk membantu siswa menemukan bilangan desimal antara 0 dengan 4 , sedangkan untuk menemukan bilangan desimal yang lebih besar dapat dimodifikasi sesuai kebutuhan. Alat tersebut dapat dibuat menggunakan bahan styrofoam sebagai model permukaan timbangan untuk dituliskan angka. Jarum yang menunjukan angka tersebut juga terbuat dari styrofoam, dapat diputar-putar oleh siswa layaknya sebuah jam dinding sesuai angka yang diinginkan. Sedangkan untuk alat yang melilit di atas model permukaan timbangan tersebut terbuat dari bahan plastik mika yang dapat ditulis angka oleh siswa dan dapat dibuka untuk dijadikan garis bilangan.

Langkah pertama dilakukan oleh guru adalah dengan bertanya kepada siswa mengenai bilanganbilangan yang terdapat diantara dua bilangan bulat pada media permukaan timbangan. Misalkan untuk menemukan bilangan desimal diantara 2 dan 3 , maka guru bertanya kepada siswa satu persatu. Contohnya tentukan arah jarum timbangan yang menunjukkan bilangan 2,5. Sambil mengarahkan jarum ke angka di model permukaan timbangan, siswa dapat menuliskan angka yang dimaksud pada bagian atas media tersebut. Guru dapat melanjutkan pertanyaan untuk bilangan lain diantara 2 dan 3 . Dengan demikian siswa dapat memahami bahwa diantara dua buah bilangan bulat terdapat banyak bilangan desimal.

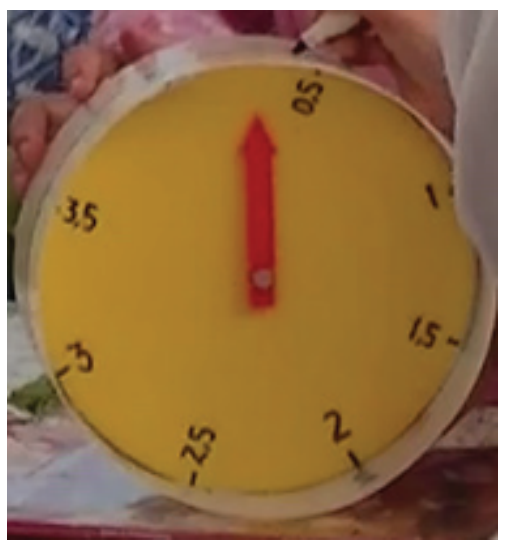

Gambar 4. Media Model Permukaan Timbangan

Bilangan-bilangan desimal yang sudah dituliskan di model permukaan timbangan, selanjutnya dijadikan garis bilangan. Tujuan dari kegiatan ini untuk membantu siswa memahami bahwa angka yang ada di timbangan juga dapat dibuat ke garis bilangan, sehingga siswa mudah memahaminya. 
Bentuk garis bilangan yang dibuka dari model permukaan timbangan seperti gambar berikut.

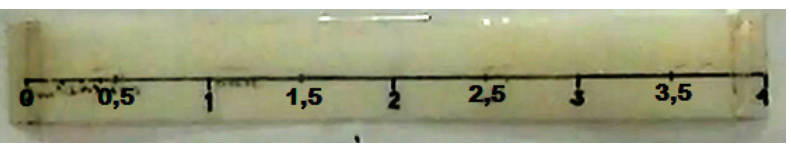

Gambar 5. Garis Bilangan dari Model Permukaan

Timbangan

Garis bilangan dari model permukaan timbangan, selanjutnya dilengkapi siswa dengan bilangan desimal diantara bilangan bulat. Garis bilangan yang dilengkapi dengan bilangan desimal yaitu seperti Gambar 4 di bawah ini.

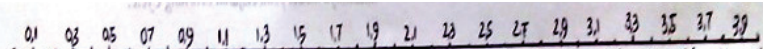

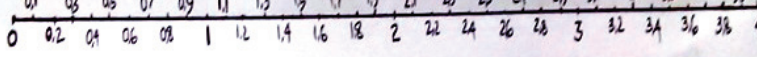

Gambar 6. Garis Bilangan yang Dilengkapi dengan Bilangan Desimal

Berdasarkan pengetahuan di atas, guru juga dapat membantu siswa menemukan bilangan desimal yang terdapat diantara 3 dan 4 atau 5 dan 6. Sehubungan dengan masalah tersebut Isiksal dan Cakiroglu (2010) menyebutkan bahwa fokus pada sebuah konsep dan hubungannya merupakan sebuah strategi yang berhubungan dengan pengetahuan formal. Dalam hal ini tidak cukup dengan pengulangan materi atau memberikan penguatan, akan tetapi guru perlu memberikan bantuan berupa penggunaan alat peraga yang kontekstual sehingga siswa dapat memahami materi dengan mudah. Selanjutnya guru juga dapat memberikan contoh soal yang bervariasi kepada siswa mengenai bilangan desimal diantara dua bilangan bulat.

Saran untuk membantu siswa yang mengalami miskonsepsi mengenai cara mengubah pecahan ke bentuk bilangan desimal dapat dilakukan dengan menggunakan model persegi panjang yang menunjukkan pecahan. Misalkan untuk membantu siswa dalam mengubah pecahan $\frac{1}{2}$ menjadi bilangan desimal, guru dapat menggunakan model persegi panjang yang menunjukkan pecahan dengan menampilkan petak yang dibagi dua dan satu bagian diarsir. Guru juga dapat menggunakan dua benda dengan berat masing-masing 500 gram, apabila kedua benda tersebut ditimbang akan menghasilkan $1 \mathrm{~kg}$. Berdasarkan proses penimbangan benda tersebut maka siswa diharapkan akan memahami, bahwa apabila satu benda ditimbang akan menghasilkan $0,5 \mathrm{~kg}$ atau setara dengan $\frac{1}{2} \mathrm{~kg}$. Selanjutnya guru dapat menjelaskan bahwa ada dua petak, yang diarsir satu petak dan bermakna $\frac{1}{2}$ atau 0,5. Langkah selanjutnya guru menampilkan model persegi panjang yang menunjukkan pecahan $\frac{5}{10}$. Pada gambar tersebut dapat dilihat oleh siswa perbandingan petak $\frac{1}{2}$ dan $\frac{5}{10}$ mempunyai ukuran yang sama, maka siswa juga dapat menyimpulkan bahwa $\frac{5}{10}$ juga bernilai 0,5 . Hal ini seperti terlihat pada gambar 7.

Berdasarkan pengalaman tersebut maka siswa juga akan mudah memahami soal mengubah pecahan $\frac{3}{10}$ dan $\frac{7}{10}$ menjadi bilangan desimal dengan cara menggunakan model persegi panjang yang menunjukkan pecahan. Misalkan untuk menentukan bilangan desimal dari pecahan $\frac{3}{10}$, maka guru dapat menyiapkan sepuluh buah benda dengan ukuran masing-masing 100 gram. Selanjutnya membuat model persegi panjang yang menunjukkan pecahan $\frac{3}{10}$. Karena pecahan bernilai $\frac{3}{10}$ maka yang diarsir adalah tiga petak dari sepuluh petak. Berdasarkan pemahaman tersebut, diambil benda yang sudah disiapkan dengan berat masing-masing 100 gram dengan mengambil tiga benda dari sepuluh benda. Langkah selanjutnya adalah menimbang ketiga benda tersebut yang masing-masing memiliki berat 100 gram sehingga bernilai 300 gram atau setara dengan $0,3 \mathrm{~kg}$. Dengan demikian siswa dapat menyimpulkan bahwa pecahan $\frac{3}{1}$ diubah ke bilangan desimal maka bernilai 0,3. Kemudian dengan menggunakan langkah yang sama siswa juge ${ }_{3}$ lapat mengubah pecahan $\frac{7}{10}$ menjadi bilangan desiinal secara tepat.

Langkah yang pertama dilakukan adalah dengan cara menyiapkan 10 buah benda dengan ukuran masing-masing 100 gram. Selanjunya dibuat model persegi panjang yang menunjukkan

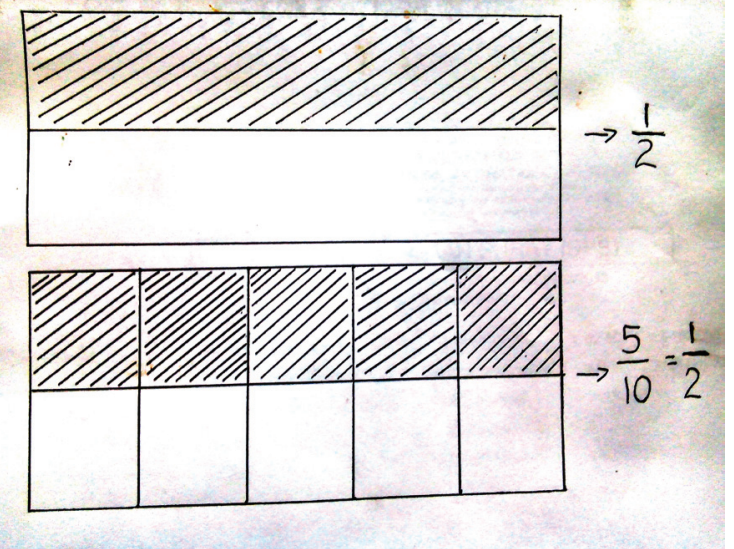

Gambar 7. Model Persegi Panjang yang Menunjukkan Pecahan 
pecahan dengan jumlah sepuluh petak. Berhubung pecahan $\frac{7}{10}$ yang akan diubah ke bilangan desimal, maka sebanyak tujuh petak diarsir dari sepuluh petak. Kemudian kegiatan ini dihubungkan dengan menimbang benda yang sudah disiapkan. Caranya adalah memberi pemahaman kepada siswa tentang makna pecahan $\frac{7}{10}$ yang artinya diambil tujuh dari sepuluh atau diarsir tujuh petak dari sepuluh petak. Dengan pemahaman tersebut maka diambil benda yang sudah disiapkan sebanyak tujuh buah dari sepuluh buah, kemudian ditimbang. Hasil menimbang tujuh buah benda yang memiliki berat masing-masing 100 gram, maka menghasilkan 700 gram atau setara dengan $0,7 \mathrm{~kg}$. Berdasarkan aktivitas tersebut siswa dapat menyimpulkan bahwa pecahan $\frac{7}{10}$ bernilai 0,7 .

Afriansyah \& Putri (2013) menyebutkan kekeliruan yang sering terjadi pada operasi bilangan desimal, disebabkan karena siswa hanya mengandalkan pengetahuan prosedur pengerjaan saja dan tidak didukung oleh pemahaman tentang konsep dibalik prosedur pengerjaan tersebut. Seperti penggunaan konsep nilai tempat pada operasi penjumlahan bilangan desimal.

Melihat bentuk miskonsepsi yang dialami oleh siswa $\mathrm{C}$, maka dapat disarankan upaya mengatasi kesalahan tersebut. Guru dapat menggunakan media berupa timbangan digital. Penggunaan timbangan digital bertujuan untuk memudahkan siswa memahami proses operasi penjumlahan bilangan desimal. Hasil penelitian Fain, et al, (2015) menunjukkan bahwa siswa sekolah dasar yang mengalami kesulitan dalam memahami matematika juga mengalami kesulitan dalam memahami kodekode terkait bilangan. Kesulitan yang terjadi pada siswa kelas rendah akan berlanjut sampai kelas tinggi. Dengan demikian, diperlukan suatu aktivitas yang dapat membantu siswa memahami perbedaan antara operasi penjumlahan pada bilangan desimal dengan bilangan bulat.

Aktivitas menggunakan timbangan digital sebagai solusi mengatasi kesalahan siswa mema-hami konsep penjumlahan bilangan desimal dapat dilakukan dengan cara menyiapkan dua buah benda yang akan ditimbang. Misalkan untuk menentukan penjumlahan 12,37 dengan 1,4. Maka guru menyiapkan benda pertama dengan berat 12,37 dan benda kedua dengan berat 1,4. Selanjutnya dilakukan aktivitas menimbang dengan cara, menimbang secara bersamaan benda yang berat 12,37 dan benda dengan berat 1,4. Dari hasil timbangan tersebut akan menghasilkan nilai 13,77. Guru juga dapat menggunakan langkah lain untuk membantu siswa memahami cara melakukan operasi penjumlahan bilangan desimal yaitu dengan penekanan tanda koma. Pada operasi bilangan desimal tanda koma menjadi kunci utama untuk mendapatkan hasil yang tepat.

Persoalan miskonsepsi yang terjadi pada siswa tidak boleh dibiarkan begitu saja. Setelah miskonsepsi terlihat pada siswa, guru harus segera menentukan strategi yang cocok untuk mengatasinya. Jika langkah diambil oleh guru adalah mengajarkan ulang materi yang membuat siswa mengalami miskonsepsi, maka harus dibuat ketegasan mengenai apa yang harus ditekankan dan bagaimana siswa mudah mengingatnya. Guru juga dapat menggunakan desain pembelajaran yang membantu siswa dalam memahami bilangan desimal. Salah satu contoh desain yang dapat digunakan adalah desain yang dikembangkan Wirda, dkk (2015) yaitu desain Hypothetical Learning Trajectory (HLT) yang terbukti mampu membantu siswa sekolah dasar memahami konsep bilangan desimal.

Dalam mengatasi miskonsepsi siswa, pendekatan yang sering digunakan oleh guru adalah berpusat pada aspek prosedural atau aspek konseptual. Hiebert \& Lefevre (dalam Cockburn, 2008) membedakan pengetahuan konseptual yang dijabarkan sebagai cara menumbuhkan relasi yang baik, sedangkan pengetahuan prosedural memfokuskan pada gambaran simbolis dan algoritmis. Ketika menjelaskan cara mengatasi masalah siswa, guru memberikan penjelasan yang selalu terfokus pada kategori konseptual atau prosedural atau keduanya. Hal ini karena kesalahan siswa dalam matematika seringkali terjadi karena siswa terlalu fokus dalam menghafalkan algoritma atau rumus dalam menyelesaikan soal (Zientek, et al, 2014). Selain itu, penyebab kesalahan siswa sekolah dasar dalam melakukan pemecahan masalah sebagian besar disebabkan oleh kurangnya pemahaman konseptual (Herholdt \& Sapire, 2014).

Kesulitan siswa dalam mengungkapkan masalah merupakan respon konseptual, maka perlu menggunakan sumber yang tepat dalam menanamkan prinsip matematika. Sebagian guru sering sekali menyebutkan bahwa miskonsepsi siswa terjadi karena teknik yang digunakan bersifat prosedural, dengan menyimpulkan sesuatu tanpa alasan yang kuat. Chick (2005) menyebutkan salah satu tantangan pembelajaran yaitu kedua 
aspek konseptual dan prosedural harus dicapai, permasalahan ini memburuk apabila guru kurang fasih dalam memahami konsep tema yang dibahas. Oleh karena itu, pemilihan starategi pembelajaran yang tepat dengan materi yang diajarkan sangat diperlukan dalam pembelajaran matematika.

\section{SIMPULAN DAN SARAN}

\section{Simpulan}

Bentuk miskonsepsi siswa yang terjadi pada pembelajaran bilangan desimal yang terlihat dari hasil tes yaitu salah menentukan bilangan desimal yang terdapat diantara dua bilangan bulat, salah mengubah bilangan pecahan menjadi bilangan desimal, dan salah melakukan operasi penjumlahan bilangan desimal. Penyebab miskonsepsi berdasarkan hasil observasi adalah contoh soal yang diberikan oleh guru kurang bervariasi sehingga generalisasi yang dilakukan siswa menjadi keliru dan waktu yang diberikan kepada siswa dalam menggunakan alat peraga terlalu singkat sehingga siswa cenderung menggunakan cara penjumlahan bersusun seperti menjumlahkan bilangan bulat.

\section{Saran}

Berdasarkan simpulan di atas, maka saran yang dapat diberikan untuk membantu siswa yang mengalami miskonsepsi dalam mempelajari bilangan desimal yaitu menggunakan model permukaan timbangan untuk menentukan bilangan desimal diantara dua bilangan bulat, memberikan contoh yang bervariasi untuk menentukan bilangan desimal diantara dua bilangan bulat, menggunakan model persegi panjang yang menunjukkan pecahan untuk mengatasi miskonsepsi siswa mengubah pecahan menjadi bilangan desimal, dan memberikan waktu yang sesuai kepada siswa menggunakan timbangan digital agar tidak mengalami miskonsepsi pada operasi penjumlahan bilangan desimal. Dengan demikian diharapkan guru dapat mengatasi miskonsepsi sehingga siswa dapat menguasai materi bilangan desimal dengan baik. Kekurangan penelitian ini adalah peneliti tidak melakukan wawancara secara mendalam dengan siswa yang mengalami miskonsepsi untuk memastikan alasan jawaban yang mereka berikan dalam menyelesaikan soal.

\section{DAFTAR RUJUKAN}

Afriansyah, E.A \& Putri, R.I.I. 2013. Konsep Nilai Tempat pda Operai Penjumlahan Bilangan Desimal di Kelas V Sekolah Dasar. Pendidikan Matematika. 7 (2), 14-24

Allen, G., D. 2000. Student Thinking. Makalah pada Department of Mathematics. Texas: A\&M University Jauhar. Diakses pada tanggal 1 Juni 2016 pada $w w w . m a t h . t a m u . e d u$.

Cockburn, A., D. dan Littler G. 2008. Mathematical Misconceptions; A Guide for Primari Teacher. London: Replika Press.

Chick, H., L. \& Baker, M., K. 2005. Investigating Teacher's Responses to StudentMisconceptions. Journal Psychology of Mathematics Education. (2), 249-256

Fain, A. C., Gallagher, P. A., \& Heller, K. 2015. Students with Emotional and Behavior Disorders: A Review of Mathematics Interventions with a Focus on Subtraction. Başkent University Journal Of Education, 2(2).

Gül, A., S, \& Mustafa, S., K. 2008. Grade 10 Students' Misconceptions about Impulse and Momentum. Journal of Turkish Science Education, 5(2), 47-59.

Herholdt, R., \& Sapire, I. 2014. An error analysis in the early grades mathematics-A learning opportunity? South African Journal of Childhood Education, 4(1), 43-60.

Isiksal, M., \& Cakiroglu, E. 2010. The Nature of Prospective Mathematics Teachers' Pedagogical Content Knowledge: The Case of Multiplications of Fractions. Journal Math Teacher Educ. (14), 213-230.

Pramudiani, P. 2011. Students' Learning Of Comparing The Magnitude Of One-Digit And Two-Digit Decimals Using Number Line A Design Research on Decimals at Grade 5 in Indonesian Primary School. Tesis Magister, Tidak diterbitkan, Pasca Sarjana Universitas Sriwijaya Palembang.

Ristanti. 2016. Peningkatan Motivasi dan Keterampilan Hitung Pecahan Desimal melalui Media Manipulatif pada Pembelajaran Tematik-Integratif SD. Jurnal Riset Pendidikan Matematika. 3 (1), 122-136

Roselizawati, Sarwadi, \& Shahrill, M. 2014. Understanding Students' Mathematical Errors and Misconceptions: The Case of Year 11 
Repeating Students. Journal Mathematics Education Trends and Research. (1). 1-10.

Suparno, P. 2013. Miskonsepsi dan Perubahan Konsep dalam Pendidikan Fisika. (Cetakan Ke-2). Jakarta: Grasindo.

Ubuz, B., \& Yayan, B. 2010. Primary Teachers'Subject Matter Knowledge: Decimals. International Journal of Mathematical Education in Science and Technology. 41(6), 787-804.

Winarni, S. 2011. Penanaman Konsep Bilangan Desimal dengan Menggunakan Kalkulator pada Siswa Kelas IV SD Negeri No.7 Ngulak. Edumatica. 1 (1), 17-24
Wirda, E., Johar, R., \& Ikhsan, M. 2015. Pengembangan Design Pembelajaran Tematik untuk Meningkatkan Pemahaman Konsep Bilangan Desimal Siswa Sekolah Dasar. Jurnal Didaktik Matematika. 2 (1), 33-45.

Zientek, L. R., Schneider, C. L., \& Onwuegbuzie, A. J. 2014. Instructors' Perceptions about Student Success and Placement in Developmental Mathematics Courses The Community College Enterprise, 20(1), 66. 